\title{
FGFR2 Gene Amplification
}

National Cancer Institute

\section{Source}

National Cancer Institute. FGFR2 Gene Amplification. NCI Thesaurus. Code C36651.

A molecular genetic abnormality indicating the presence of multiple copies of the FGFR2 gene. 